\title{
Correspondence
}

\section{Monster fern makes IUCN invader list}

The list of 100 of the world's worst invasive alien species, compiled by the International Union for Conservation of Nature (IUCN), aims to help biodiversity conservation efforts worldwide (see go.nature.com/qa9z1g). After a position on the list fell vacant as a result of the global eradication of the rinderpest virus (see, for example, Nature 474, 10-11;2011), we coordinated the community of invasion biologists in a unique initiative to vote for a replacement.

We assessed more than 10,000 invasive species from the world's largest databases for their capacity to spread and for their potential ecological or economic impact. More than 650 experts from 63 countries then voted on the ten candidate species we shortlisted, and selected the giant salvinia (Salvinia molesta), an aquatic fern.

Native to Brazil, this fern has spread throughout the tropics and subtropics. It doubles in abundance within days, forming thick, floating mats that block light from expanses of water, reduce its oxygen content and degrade water quality. They also impede water-based transport, clog irrigation and powergeneration systems, and harm local fisheries.

Now in the global spotlight, this new entrant to the IUCN list is set to increase public awareness of the harm caused by invasive species and to stimulate more discussion in science and policy circles. Franck Courchamp ${ }^{\star}$ CNRS; University of Paris-Sud, Orsay, France.

franck.courchamp@u-psud.fr ${ }^{*}$ On behalf of 7 co-signatories. See go.nature.com/wvjef 2 for full list.

\section{Avoid more organ transplant scandals}

Our institution is launching an international transdisciplinary initiative to improve the lamentable state of solid-organ transplantation in Germany and to help fulfil society's obligations towards millions of organ donors and recipients worldwide (see go.nature.com/z5b7uo).

The mortality rate following liver transplantation has risen alarmingly across the country over the past few years. The survival rate after one year is only $72 \%$ in Germany, which is $20 \%$ lower than in the United States and the United Kingdom, even though Germany has more transplant centres and fewer organ donors per capita (see go.nature.com/pgmrpn; in German). Such scandals are leading to a steady decline in altruistic organ donations, with an $18 \%$ drop in the first quarter of this year compared with the same period in 2012

The situation largely reflects the weak regulation of organ transplantation in Germany, especially by comparison with other countries such as the Netherlands and Denmark (C. Metz and N. Hoppe Eur. J. Health Law 20, 113-116; 2013). Proposals to rectify this include setting up an independent institute of transplantation medicine that has regulative and standard-setting powers (see go.nature.com/yzl4km; in German).

A lack of good prognostic models compounds the likelihood of transplantation failure. Such models would allow clinical urgency to be weighed against transplantation outcome. We are therefore planning systematic multicentre trials to evaluate the prognostic value of liver-allocation scores.

Our initiative also aims to address the dearth of qualitymanagement systems that are properly founded on comprehensive, evidence-based data and on precise methodology that considers patients' needs and expectations.

The early results are promising. We intend to publish regular updates to provide essential information to the transplantation community and to ensure openness to the public.

Harald Schrem Hannover

Medical School, Germany.

schrem.harald@mh-hannover.de

Alexander Kaltenborn

Hannover Medical School; and

Federal Armed Forces Medical

Centre, Hannover, Germany.

\section{Satellites: make data freely accessible}

The cost of accessing satellite

data is hampering the

widespread application of

satellite monitoring, a vital tool

for controlling deforestation

(Jim Lynch et al. Nature

496, 293-294; 2013) and for

biodiversity assessments. We

urge government agencies

that produce taxpayer-funded

satellite images to make these available free of charge and in user-friendly formats.

Lynch and colleagues' call for daily satellite observations of forests worldwide would mean aggregating information from numerous satellites that are operated by many countries. Assembling the large data sets needed for global monitoring would be prohibitively expensive, however, because national governments do not have a free-access policy for their satellite images.

One solution would be to combine data from the US Landsat satellites with those from the European Space Agency's planned Sentinel-2 satellites, which could deliver optical imagery with global coverage every $3-5$ days. The distribution of Landsat imagery has increased by two orders of magnitude since 2008, when the US Geological Survey made all the data free to access online. Data from NASA's MODIS and all of their Earth-observation imagery are also available for free, as are data from the ChinaBrazil Earth Resources Satellite programme.

Woody Turner ${ }^{\star}$ Earth Science Division, NASA, Washington DC, USA. woody.turner@nasa.gov

${ }^{\star}$ On behalf of 14 co-signatories. See go.nature.com/pfv6an for full list.

\section{Satellites: ambition for forest initiative}

We disagree strongly with the suggestion by Jim Lynch and colleagues that the outputs of the Global Observation of Forest and Land Cover Dynamics panel and the Global Forest Observations Initiative "lack ambition and an understanding of the potential of satellites" (Nature 496, 293-294; 2013).

As participants in these programmes and in the United Nations Programme on Reducing Emissions from Deforestation and Forest Degradation (UN-REDD), we aim to show how remote sensing can help systematic global monitoring to make REDD+a reality in the context of wider societal engagement. (REDD+ is a climate-mitigation initiative under the UN Framework Convention on Climate Change (UNFCCC).)

We also question the feasibility of Lynch and colleagues' call for rapid-response satellite monitoring of deforestation to be enshrined in international law under the UNFCCC, given national sovereignty concerns and the fact that we are not yet in a position to mitigate the problems of cloud cover. Although radar can penetrate cloud, the technology cannot yet capture changes in forest ecosystems in a systematic and repeatable way. Giles Foody ${ }^{\star}$ University of Nottingham, UK. giles.foody@nottingham.ac.uk ${ }^{\star}$ On behalf of 7 co-signatories. See go.nature.com/wulf3e for full list.

\section{CONTRIBUTIONS}

Correspondence may be sent to correspondence@ nature.com after consulting the author guidelines at http://go.nature.com/ cmchno 